\title{
INHIBITION OF BISPECIFIC MONOCLONAL ANTIBODY (bsAb)-TARGETED CYTOLYSIS BY HUMAN ANTI-MOUSE ANTIBODIES IN OVARIAN CARCINOMA PATIENTS TREATED WITH bsAb-TARGETED ACTIVATED T-LYMPHOCYTES
}

\author{
Cor H.J. Lamers ${ }^{1}$, Jan W. Gratama', Sven O. WARnAar ${ }^{3}$, Gerrit Stoter ${ }^{2}$ and Reinder L.H. Bolhuis ${ }^{1.4}$ \\ Departments of ${ }^{1}$ Clinical and Tumor Immunology and ${ }^{2}$ Medical Oncology, Daniel den Hoed Cancer Center, Rotterdam; \\ and ${ }^{3}$ Centocor Europe B.V., Leiden, The Netherlands.
}

\begin{abstract}
T lymphocytes of 8 patients with ovarian cancer were targeted to the tumor cells using $F\left(\mathbf{a b}^{\prime}\right)_{2}$ fragments of a bispecific monoclonal antibody (bsAb), specific for CD3 (a component of the $T$ lymphocyte receptor for antigen) and for the folate receptor MOv 18 (overexpressed by ovarian carcinoma cells) as part of a phase $I / I$ study. Phase $I$ (days 0 to 3 ) consisted of increasing intraperitoneal (i.p.) numbers $\left(10^{6}-10^{9}\right)$ of bsAbtargeted T lymphocytes plus low-dose interleukin-2 (IL-2). Phase II (days 6 to 13, and 27 to 33) consisted of daily i.p. infusions of $10^{\circ}$ targeted T lymphocytes, $2 \mathrm{mg}$ soluble bsAb, and low-dose IL-2. Using enzyme-linked immunosorbent assays (ELISA), human anti-mouse antibodies (HAMA) were detected in all patients: in the serum from day 13 onwards and in the peritoneal fluid from day $\mathbf{2 0}$ onwards. A significant proportion of the HAMA appeared to be directed against the idiotypes of the bsAb specific for $C D 3$ and MOv 18, as suggested by (I) the clearly higher ELISA titers against OC/TR bSAb as compared to those against a monocional antibody (MAb) with unrelated specificity, and (2) failure to abrogate the capacity of peritoneal fluid containing HAMA to block the binding of OC/TR bsAb to MOv $18^{+}$or $\mathrm{CD}^{+}$cells by absorption of human anti-mouse IgG-framework antibodies in peritoneal fluid to immobilized mouse IgG. The OC/TR-targeted cytolysis of the MOvI8 ovarian carcinoma cell line Igrov-I by autologous $T$ lymphocytes was inhibited by peritoneal fluid samples containing relatively high HAMA titers. Such inhibitory activity was never detected at the start of phase II, but coincided with the last series of i.p. infusions of targeted T lymphocytes in 2 patients.

(c) 1995 Wilev-Liss, Inc.
\end{abstract}

Mouse MAbs directed against tumor-associated antigens (TAA) and conjugated to radioisotopes, chemotherapeutic agents or toxins are increasingly being used for in vivo diagnosis and treatment of malignancies (Mach et al., 1981; Schroff et al., 1985). The infusion of murine immunoglobulins (Ig) elicits human anti-mouse Ig antibody (HAMA) responses. Such HAMA responses have been reported in clinical studies of tumor imaging (Courtenay-Luck et al., 1986) and tumor therapy (Schroff et al., 1985; Courtenay-Luck et al., 1988; Saleh et al., 1993). HAMA responses develop over a wide dose range (i.e., from $<1 \mathrm{mg}$ to $>1 \mathrm{~g}$ ) (Khaezali et al., 1988), and occur more frequently after repeated administrations of MAbs (Lind et al., 1991). Fab fragments of murine MAbs and genetically engineered mouse-human MAbs are less immunogenic than intact murine Ig molecules (reviewed by Khaezali et al., 1994). Initially, HAMA with specificities for the constant regions of murine Ig develop, followed by HAMA with anti-idiotypic specificities. These latter antibodies develop particularly well after multiple administrations of MAbs (Schroff et al., 1985; Saleh et al., 1993). Adverse clinical reactions upon administration of MAbs to patients with pre-existing HAMA are uncommon, but a highly increased clearance of the administered MAb is seen in such patients, which may prevent the MAbs from interacting with their target (Khazaeli et al., 1994).

Targeting of the cytolytic activity of $T$ lymphocytes against tumor cells can be achieved using bispecific monoclonal antibodics (bsAbs) which are directed against a T-cell activation epitope on the one hand (e.g., CD3) and a TAA on the other. Targeting of cytotoxic $\mathrm{T}$ lymphocytes (CTL) with bsAb results in selective destruction of tumor cells following $\mathrm{MHC}$ unrestricted binding of the CTL to tumor cells (Segal and Snider 1989; Van Dijk et al., 1989). This approach has been effective in reducing or eliminating tumor in several mouse model systems (Segal and Snider, 1989), in human malignant glioma (Nitta et al., 1990) and in ovarian carcicoma (Bolhuis et al., 1992). The OC/TR bsAb is specific for CD3 and MOv18 (Mezzanzanica et al., 1988). MOv18 has been identified as the glycosyl-phosphatidyl-inositol (GPI)-anchored, high-affinity folate-binding protein gp38 (Coney et al., 1991), and is overex pressed on ovarian carcinoma cells as compared to normal ovarian cells. The OC/TR bsAb was used as part of the intraperitoneal (i.p.) treatment of ovarian carcinoma in a phase-I/II clinical trial (Bolhuis et al., 1992). Patients entered into this trial received 10 therapeutic i.p. infusions with OC/TR and autologous OC/TR-targeted activated T lymphocytes. This report concerns the kinetics of HAMA responses in these patients and the interference of HAMA with bsAbtargeted cytolysis.

\section{MATERIAL AND METHODS}

\section{Clinical study}

Eight ovarian-carcinoma patients were treated with i.p. infusions of targeted T lymphocytes and the bsAb OC/TR in a phase-I/II clinical trial. Patients with advanced epithelial ovarian carcinoma (FIGO stage III, MOv18-positive tumor, and thickness of residual tumor lesions of less than $2 \mathrm{~cm}$ after debulking surgery), were eligible. $T$ lymphocytes were activated in vitro and expanded using phytohemagglutinin (PHA Wellcome, Dartford, UK) and interleukin-2 (IL-2; Proleukin, Eurocetus, Amsterdam, The Netherlands) as described previously (Lamers et al., 1992). The bsAb OC/TR F $\left(\mathrm{ab}^{\prime}\right)_{2}$ fragments were produced by Centocor Europe (Leiden, The Netherlands). Prior to i.p. administration, the cultured $T$ lymphocytes were incubated for $30 \mathrm{~min}$ at $37^{\circ} \mathrm{C}$ with $\mathrm{OC} / \mathrm{TR}$ bs Ab ( $1 \mathrm{mg}$ per $10^{6}$ to $10^{9}$ viable cells; Table I). Thereafter, unbound bsAb was washed away in phase I but was not removed in phase $\mathrm{II}$, and $0.6 \times 10^{6} \mathrm{IU} \mathrm{IL}-2$ were added prior to administration in all cases. According to the schedule (Table I) the patients were to receive 3 cycles of i.p. therapy of autologous OC/TR-labeled T lymphocytes, soluble OC/TR and IL-2. Thus, they should have received a total of $10 \times 10^{9}$ OC/TR-labeled T lymphocytes, $28 \mathrm{mg} \mathrm{OC} / \mathrm{TR}$ bsAb and $16.8 \times 10^{6}$ IU IL-2 during phase II. The actual treatment differed from schedule in 3 of the 8 patients. Patient 2 received a third therapeutic cycle from days 48 to 52 because her first therapeutic cycle was considered inadequate due to insufficient fluid distribution in the peritoneal cavity. For patient 6 ,

${ }^{4}$ To whom correspondence and reprint requests should be sent, at the Department of Medical and Tumor Immunology, Daniel den Hoed Cancer Center, P.O. Box 5201, 3008 AE Rotterdam, The Netherlands. Fax: 31104841885 .

Received: July 4, 1994 and in revised form October 19, 1994 
the interval between phase I and the first therapeutic cycle of phase II was extended to 14 days because of slow in vitro expansion of the autologous $\mathrm{T}$ lymphocytes. Treatment of patient 8 was abrogated on day 28 (i.e., after the first day of the second therapeutic cycle) due to her poor clinical condition. Serum and peritoneal fluid samples were taken prior to the first infusion and on days $6,13,27,34,49$, and around days 70 and 100 . Serum and peritoneal fluid samples were cleared from cells and debris by centrifugation and stored at $-80^{\circ} \mathrm{C}$ until further investigation.

\section{Detection of human anti-mouse antibodies (HAMA)}

The presence of HAMA in serum and peritoneal fluid samples was assessed using a 2-step sandwich enzyme-linked immunosorbent assay (ELISA). As solid phase, $F\left(a b^{\prime}\right)_{2}$ fragments of the OC/TR bsAb $\left(\mathrm{IgG}_{1} / \mathrm{IgG}_{1}\right)$, of the $323 / \mathrm{A} 3 \mathrm{MAb}$ (an $\mathrm{IgG}_{1}, \kappa \mathrm{MAb}$ with pan-carcinoma specificity; Edwards t al., 1986) and of the MOv18 MAb (IgG $1, \kappa)$ were used (all from Centocor Europe, Leiden). The tracer antibody was goat anti-human $\mathrm{Fc}(\mathrm{IgG})$ conjugated with alkaline phosphatase (Affipure; Jackson Immunotech, West Grove, PA) and the substrate was p-nitrophenylphosphate disodium dissolved in 2-amino-2-methyl-1-propanol (Sigma, St. Louis, MO) at $\mathrm{pH}$ 10.3. The wells of 96 -well microtiter plates (Nunc, Roskilde, Denmark) were coated with $2 \mu \mathrm{g}$ of antibody in $50 \mu \mathrm{l}$ of $0.1 \mathrm{M}$ glycine, $0.5 \mathrm{mM}$ EDTA, $\mathrm{pH} 8.5$, for $16 \mathrm{hr}$ at $4^{\circ} \mathrm{C}$. After washing with PBS ( $\mathrm{pH} 7.4)$, free binding sites on the matrix were blocked with $150 \mu .1 \mathrm{PBS}$ containing $1 \% \mathrm{BSA}$, for $1 \mathrm{hr}$ at $37^{\circ} \mathrm{C}$. The assay samples $(80 \mu \mathrm{l} /$ well $)$, diluted in PBS $+1 \%$ BSA, were incubated for $2 \mathrm{hr}$ at $37^{\circ} \mathrm{C}$. The initial dilution was $1: 20$. A HAMA-positive serum and a pool of normal human sera were run with each assay plate as positive and negative controls, respectively. The plates were washed 5 times with PBS containing $0.1 \%$ Tween- 20 and incubated with $75 \mu \mathrm{l} /$ well of tracer antibody (diluted 1:2,000 in PBS + 1\% BSA) for $1 \mathrm{hr}$ at $37^{\circ} \mathrm{C}$. After washing with PBS $+0.1 \%$ Tween-20, the plates were incubated with $100 \mu \mathrm{l} /$ well substrate for $30 \mathrm{~min}$ at $37^{\circ} \mathrm{C}$, and the reaction was abrogated by adding $50 \mu \mathrm{l} 3 \mathrm{~N} \mathrm{NaOH}$. The optical density (OD) was read at $405 \mathrm{~nm}$. The reciprocal dilution of the serum sample with $\mathrm{OD}_{405}=1.0$ was arbitrarily referred to as the HAMA titer.

\section{Removal of human antibodies to murine $\operatorname{Ig} G$ from peritoneal fluid}

Human anti-murine IgG antibodies were removed from sera and peritoneal fluid by affinity absorption using mouse IgG (Sigma) coupled to Affi-gel 10 (BioRad, Richmond, CA). For coupling, $10 \mathrm{mg}$ mouse IgG in $0.5 \mathrm{ml} 1 \mathrm{M} \mathrm{NaCl}, 80 \mathrm{mM} \mathrm{CaCl}$ and $0.1 \mathrm{M}$ HEPES ( $\mathrm{pH} 7.2$ ), was incubated with $1 \mathrm{ml}$ Affi-gel 10 for $4 \mathrm{hr}$ at $4^{\circ} \mathrm{C}$ on a roller bank. Residual reactive Affi-gel binding sites were blocked by incubation with $0.1 \mathrm{M}$ ethanolamine-HCl for $1 \mathrm{hr}$. For absorption of human antibodies to murine $\operatorname{lgG}, 1 \mathrm{ml}$ peritoneal fluid was mixed with $0.25 \mathrm{ml}$ of coupled Affi.gel 10 and incubated for $16 \mathrm{hr}$ at $4^{\circ} \mathrm{C}$ on a roller bank. Thereafter, the peritoneal fluid was separated from the Affi-gel 10 by centrifugation. This absorption procedure was repeated once with freshly coupled Affi-gel 10 . The processed peritoneal fluid samples were tested for residual HAMA using the ELISA described above.

Flow cytometric assay of HAMA-mediated inhibition of $O C / T R$ bs Ab binding to Igrov-I and DII cells

The MOv18 $18^{+}$ovarian carcinoma-derived cell line Igrov-1 (Bénard et al., 1985) and the $\mathrm{CD}^{+}, 4^{+}, 8^{+}, \mathrm{TCR} \alpha \beta^{+} \mathrm{CTL}$ clone D11 (Van de Griend et al., 1984) were used to analyze HAMA-mediated inhibition of binding of OC/TR bsAb to these cells. From each cell line, $50 \mu \mathrm{l}$ containing $0.50 \times 10^{6}$ cells were incubated for $30 \mathrm{~min}$ at $0^{\circ} \mathrm{C}$ with $50 \mu$ l of (1) PBS + $1 \% \mathrm{BSA}$; (2) $1 \mu \mathrm{g} / \mathrm{ml}$ OC/TR bsAb; (3) W6/32 (anti-HLAA,B,C MAb obtained from SeraLab, Crawley Down, UK) diluted in PBS + 1\% BSA; (4) HAMA containing peritoneal fluid (diluted 1:2 in PBS + 1\% BSA); (5) same as (4), with OC/TR bsAb; and (6) same as (4), with W6/32 MAb added 30 min prior to the assay. Thereafter, the cells were washed once and incubated with goat-anti-mouse Ig conjugated with phycoerythrin (PE; Southern Biotechnology, Burlington, VA) for another $30 \mathrm{~min}$ at $0^{\circ} \mathrm{C}$. After washing once, the cells were fixed in PBS containing $10 \mathrm{mg} / \mathrm{ml}$ paraformaldehyde and analyzed using a FACScan flow cytometer (Becton Dickinson, San Jose, CA). For data acquisition, list mode data of 10,000 cells per sample were obtained. In the analyses of those data, dead cells and cell fragments were excluded on the basis of their low forward light scatter signals, after which PE fluorescence characteristics were studied using histogram statistics.

\section{Cytotoxicity (CTX) assay}

Cytolytic activities were assessed in a standard 3-hr ${ }^{51} \mathrm{Cr}$ release assay, using $\mathrm{T}$ lymphocytes from ovarian cancer patients, activated and expanded using PHA + IL-2, and the CTL clone D11, specific for HLA-Cw3, as effector cells (Bolhuis and Van de Griend, 1985). The ovarian carcinoma cell line Igrov-1 and the Epstein-Barr virus-transformed, HLA-Cw3+ lymphoblastoid cell line BSM served as the source of target cells. The CTX assay medium was RPMI-1640 supplemented with $10 \%$ newborn bovine calf serum (GIBCO, Grand Island, NY). The effector cells were pre-incubated with $\mathrm{OC} / \mathrm{TR}$ for $30 \mathrm{~min}$ at $37^{\circ} \mathrm{C} ; 100 \mu \mathrm{g} / \mathrm{ml}$ of $\mathrm{OC} / \mathrm{TR}$ were sufficient for optimal targeting of cloned and bulk-cultured CTL (Mezzanzanica et al., 1988). In one experiment, chimeric $\mathrm{F}\left(\mathrm{ab}^{\prime}\right)_{2} \mathrm{OC} / \mathrm{TR}$ (chOC/TR; Centocor Europe), in which the murine constant part of the antibody was replaced by the corresponding human constant part, was used to target D11 cells. Varying numbers of effector lymphocytes were seeded in triplicate in 96-well, round-bottomed microtiter plates (100 $\mu \mathrm{l} /$ well), followed by 2,500 target cells in $100 \mu \mathrm{l}$ per well. The target cells were labeled with $100 \mu \mathrm{Ci}^{51} \mathrm{Cr}$ per $0.5 \times 10^{6}$ cells for $2 \mathrm{hr}$ at $37^{\circ} \mathrm{C}$. The effector to target $(\mathrm{E}: \mathrm{T})$ ratios used in most cases were 50,25, 12 and 6:1. At the end of the 3-hr incubation period $\left(37^{\circ} \mathrm{C}\right.$ and $\left.5 \% \mathrm{CO}_{2}\right)$, supernatants were collected and ${ }^{51} \mathrm{Cr}$ release was measured in a gamma-counter. The percentage of specific lysis was calculated according to standard formulas. The data were expressed as percentage specific lysis for each of the $4 \mathrm{E}$ : $T$ ratios tested.

For analysis of the interference of HAMA in peritoneal fluid with in vitro $\mathrm{OC} / \mathrm{TR}$-mediated cytolytic activity, autologous $\mathrm{T}$ lymphocytes that had been activated and expanded using PHA and IL-2 were targeted with $\mathrm{OC} / \mathrm{TR} \mathrm{F}\left(\mathrm{ab}^{\prime}\right)_{2}$ as described above, and subsequently washed twice to remove unbound OC/TR. OC/TR-targeted or untargeted $\mathrm{T}$ lymphocytes were resuspended in undiluted, heat-inactivated $\left(30 \mathrm{~min}\right.$ at $\left.56^{\circ} \mathrm{C}\right)$ peritoneal fluid samples. The target cells were resuspended in the corresponding peritoneal fluid samples. A similar CTX assay performed in CTX assay medium instead of peritoneal fluid served as positive control in each experiment, whilst CTX assays using untargeted $\mathrm{T}$ lymphocytes served as negative controls.

\section{RESULTS}

HAMA in serum and peritoneal fluid become detectable during therapy and contain anti-idiotypic antibodies

HAMA became detectable in the serum and peritoneal fluid of all 8 patients during treatment (Fig. 1). Serum IgG antibodies reactive with $\mathrm{OC} / \mathrm{TR}$ bsAb were first detectable after a median of 20 days (range 13 to 27 ) and reached their peak after a median of 49 days (range 27 to 70 ) after the start of phase I. The median peak serum titer was 107,000 (range 511 to $1.4 \times 10^{6}$ ). Serum $\operatorname{IgG}$ antibodies reactive with $323 / \mathrm{A} 3$ showed similar kinetics but reached lower titers (median peak serum titer, 12,000 [range 50 to 45,000 ]). Thus, it appeared 

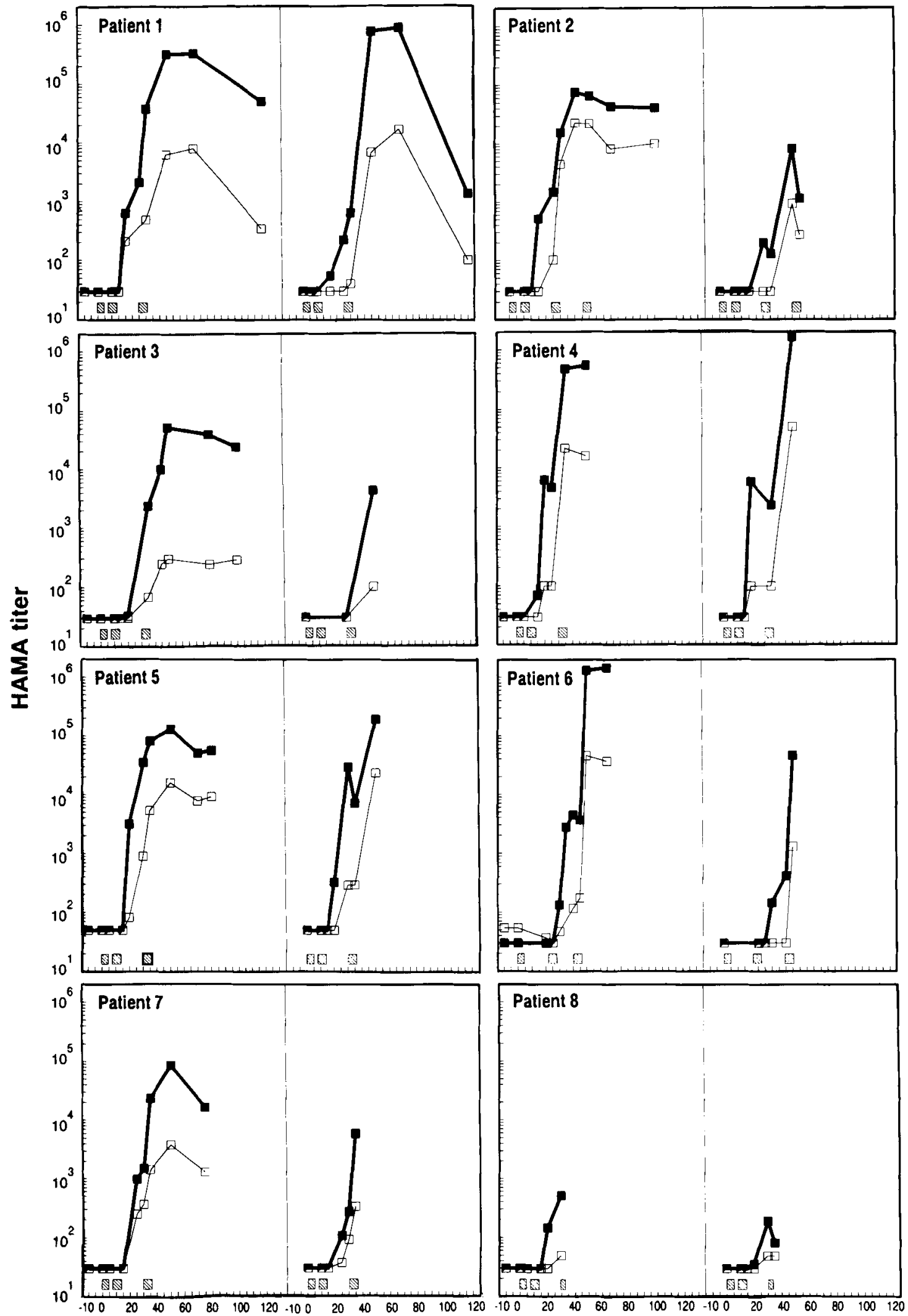

\section{Days After Start of Phase I Therapy}

FIGURE 1 - HAMA titers in sequential serum and peritoneal fluid samples from 8 patients. For each patient, serum titers are set out in the left panel and peritoneal fluid titers in the right panel. HAMA titers against OC/TR bsAb are represented by closed symbols connected by bold lines; those against 323/A3 MAb (with specificity unrelated to that of OC/TR) by open symbols connected by thin lines. Hatched boxes represent time periods during which immunotherapy ( 1 phase-I cycle, followed by 2 to 3 phase-II cycles) was administered. Logarithmic scales were used for the $Y$ axes in order to compress the figures. 
that a significant component of HAMA was directed against the idiotypes of DC/TR bsAb.

The kinetics of IgG antibody titers reactive with OC/TR bs $A b$ or $323 / \mathrm{A} 3 \mathrm{MAb}$ in peritoneal fluid paralleled those in the serum. HAMA reactive with $\mathrm{OC} / \mathrm{TR}$ bsAb were first detectable after a median of 22 days (range 20 to 34) and reached their peak after a median of 48 days (range 27 to 70 ) after the start of phase I. The median peak titer was 27,000 (range 200 to $1.6 \times 10^{6}$ ). As in the serum, the titers of HAMA reactive with $323 / \mathrm{A} 3$ were lower than those reactive with OC/TR bsAb (median peak titer, 1,075 [range 45 to 50,000$]$ ). The fluctuations of HAMA titers in the peritoneal fluid observed in patients 2,4 and 5 may have been caused in part by dilution by the i.p. infusions of targeted $T$ lymphocytes $(2 \times 500 \mathrm{ml}$ daily) and by the rinsing of the peritoneal cavity with saline between the 2 therapeutic cycles.

Further evidence that HAMA by and large comprised anti-idiotypic antibodies reactive with OC/TR bsAb was obtained by the observation that removal of human anti-mouse IgG antibodies by absorption to murine IgG coupled to Affi-gel 10 from the day-48 peritoneal fluid sample of patient 2 did not abrogate its capacity to block the binding of OC/TR bsAb to Igrov-1 ovarian carcinoma cells or to the CTL clone D11. The 2-fold absorption procedure of this specimen with mouse IgG coupled to Affi-gel 10 led to a $98 \%$ reduction in titer of antibodies reactive with 323/A3 MAb (i.e., from 4,200 to 70 ), whilst only a $43 \%$ reduction in titer of antibodies reactive with OC/TR bsAb was seen (i.e., from 11,300 to 6,400 ). Figure 2 shows that addition of OC/TR bsAb to both unabsorbed (upper panels) and absorbed (lower panels) peritoneal fluid, 30 min prior to incubation with D11 or Igrov-1 cells, led to clear reductions in the levels of reactivity with these cell types (i.e., approaching those of the respective peritoneal fluid samples in the absence of OC/TR bsAb) as compared to the levels of reactivity obtained with OC/TR added to PBS $+1 \%$ BSA. In contrast, addition of W6/32 MAb with specificity different from that of OC/TR (i.e, anti-HLA$A, B, C)$ to unabsorbed peritoneal fluid led only to partial reductions in the levels of reactivity with D11 and Igrov-1 cells as compared to the levels of reactivity obtained with W6/32 added to PBS + 1\% BSA (Fig. 2, upper panels). Moreover, the reactivity of $\mathrm{W} 6 / 32 \mathrm{MAb}$, following addition to absorbed peritoneal fluid, with D11 and Igrov-1 cells was only slightly lower than that of W6/32 added to PBS + $1 \%$ BSA (Fig. 2, lower panels). These results confirmed that HAMA comprised both anti-murine IgG-framework and anti-idiotypic antibodies reactive with OC/TR bsAb.

\section{Interaction between HAMA and $O C / T R$-targeted cytolysis of Igrov-I ovarian carcinoma cells}

Since MOv18 is shed, although to a limited extent, from the surface of fresh ovarian tumor cells and cell lines (Miotti et al., 1992), ascitic or peritoneal fluid samples from such patients may contain free MOv18 glycoproteins which may interfere with in vitro assays of OC/TR-targeted cytolysis. However, we observed that the levels of bsAb-targeted cytolysis of Igrov-1 cells in the presence of peritoneal fluid obtained prior to treatment (day 0 ) were similar to those in the presence of standard assay medium in all of the 7 patients investigated in this respect (Fig. 3).

Next, we studied whether or not peritoneal fluid samples containing HAMA could inhibit OC/TR-targeted cytolysis of Igrov-1 cells. Inhibition was detected in peritoneal fluid samples of 6 of the 8 patients, and particularly in samples with relatively high HAMA titers (Fig. 3). Seven of 8 peritoneal fluid samples with HAMA titers of 5,778 or more inhibited OC/TR-targeted cytolysis of Igrov-1 cells vs. only 1 of 20 samples with HAMA titers $<5,778$ (Fisher's exact test, $p<0.001)$. Inhibition was only detected after completion of phase II in 4 patients $(1,4,6$ and 7$)$, but coincided with therapy

\section{CTL D11}

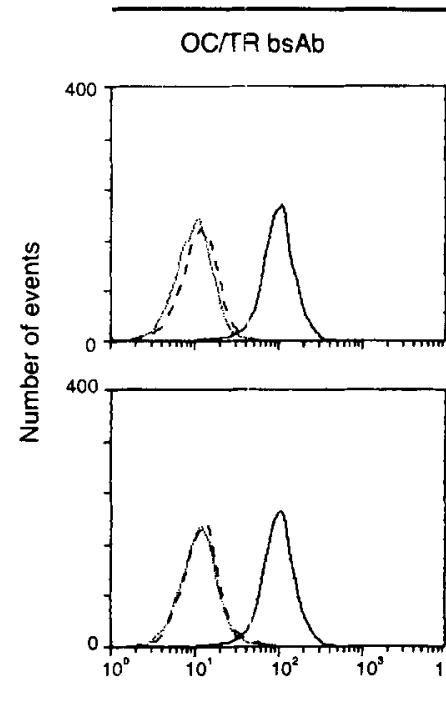

W6/32 anti-HLA-A,B,C mAb
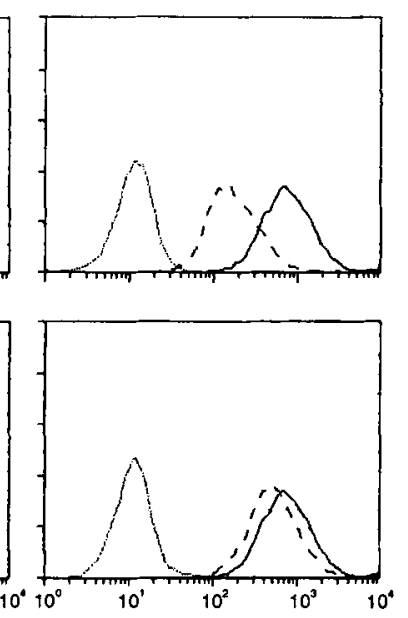

Igrov-1 Ovarian Carcinoma Cell Line

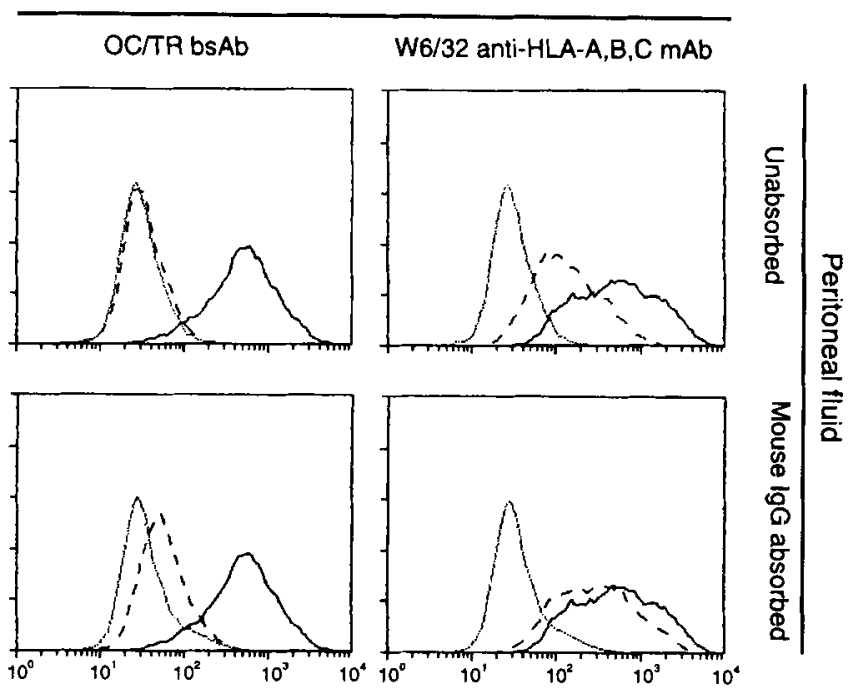

Log fluorescence intensity

FIGURE 2 - Interaction between OC/TR bsAb and unabsorbed (upper panels) or mouse IgG-absorbed (lower panels) peritoneal fluid containing HAMA led to clear reductions in the levels of OC/TR reactivities with CTL D11 and the Igrov-1 ovarian carcinoma cell line. In contrast, reactivity of $\mathrm{W} 6 / 32 \mathrm{MAb}$ (anti-HLA-A,B,C) with those cell types was only partially or minimally blocked by interaction with unabsorbed or absorbed peritoneal fluid, respectively. The day-48 peritoneal fluid sample of patient 2 was used. Prior to absorption, the HAMA titer against OC/TR bsAb was 11,300 and the titer against 323/A3 MAb was 4,200. Following absorption, these titers were 6,400 and 70 , respectively. Uninterrupted lines: reactivity of D11 or Igrov-1 cells with OC/TR or W6/32, visualized using GAM/IgG/PE; interrupted lines: reactivity of D11 or Igrov-1 cells with OC/TR or W6/32 that had been pre-incubated with unabsorbed or absorbed peritoneal fluid; dotted lines; reactivity of D11 or Igrov-1 cells with GAM/IgG/PE after incubation with unabsorbed or absorbed peritoneal fluid. 

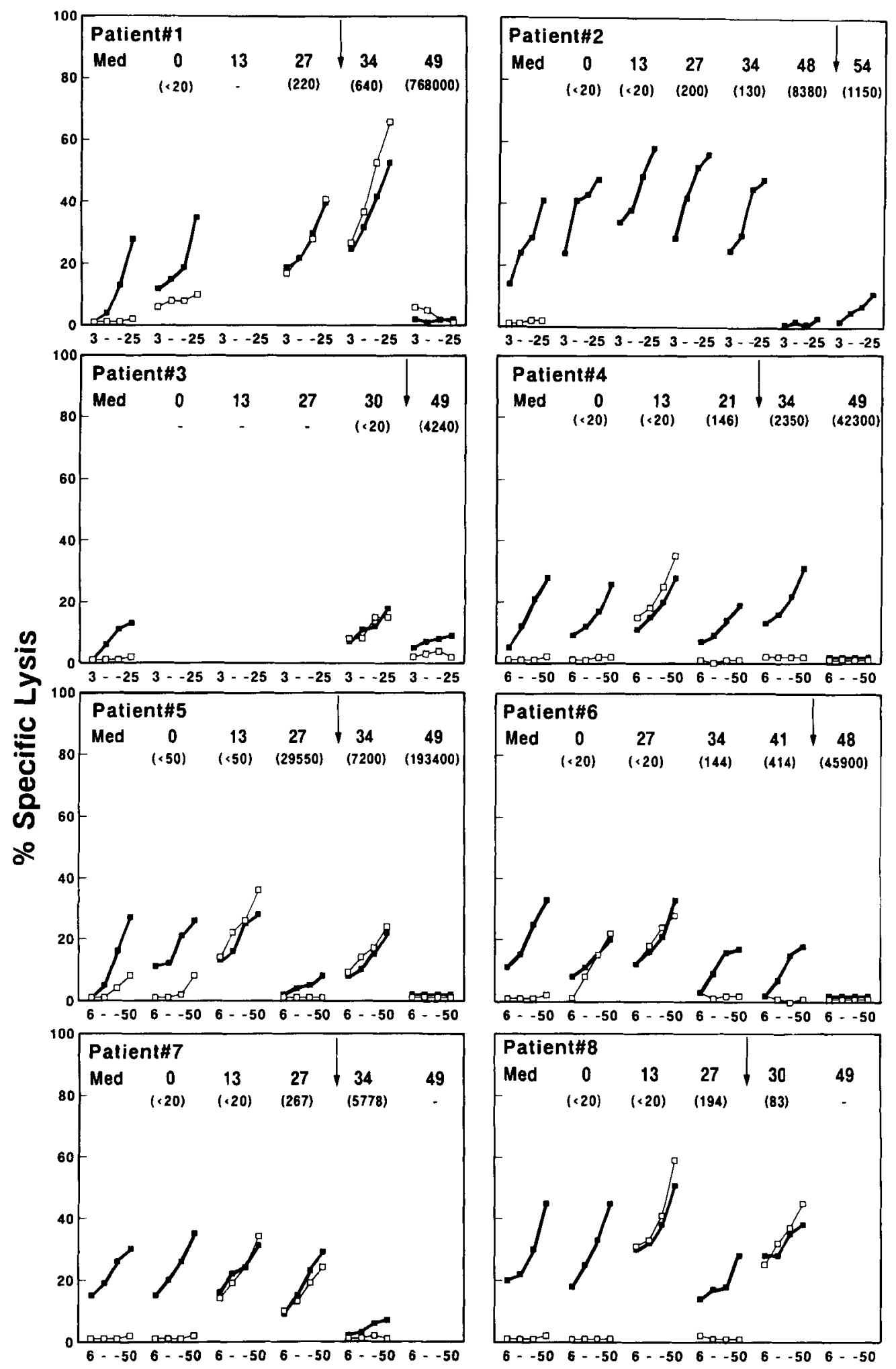

E:T Ratio for Each Assay in Medium or Peritoneal fluid

Figure 3 - Interaction between HAMA in sequential peritoneal fluid samples and OC/TR-targeted cytolysis of Igrov-1 ovarian carcinoma cells by autologous T lymphocytes activated and expanded using PHA + IL-2. The sampling time point of each peritoneal fluid sample is indicated as day relative to start of phase I. Arrows indicate the end of phase II. The HAMA titer against OC/TR bsAb (ELISA assay) is indicated between brackets for each peritoneal fluid sample. CTX assays using OC/TR-targeted T lymphocytes as effector cells are represented by closed symbols connected by bold lines; the corresponding assays using untargeted $\mathrm{T}$ lymphocytes are represented by open symbols connected by thin lines. CTX assays performed in CTX assay medium (indicated by "Med") instead of peritoneal fluid served as positive controls for OC/TR-targeted cytolysis of Igrov-1 cells in each experiment. The E:T ratios in assays designated 3-25 were $3,6,12$ and $25: 1$, respectively; those in assays designated 6-50 were $6,12,25$ and 50 , respectively. All peritoneal fluid samples were heat-inactivated $\left(30 \mathrm{~min}\right.$ at $\left.56^{\circ} \mathrm{C}\right)$ prior to the CTX assays. 
TABLE I - TREATMENT SCHEDULE

\begin{tabular}{|c|c|c|c|}
\hline Phase & Day of therapy & $1^{\text {st }}$ Infusion 1.2 & $2^{\text {nd }}$ Infusion ${ }^{1,2}$ \\
\hline I & $\begin{array}{l}0 \\
1 \\
2 \\
3\end{array}$ & $\begin{array}{l}10^{6} \mathrm{Ly} \times \mathrm{OC} / \mathrm{TR}^{3}+\mathrm{IL} 2 \\
10^{7} \mathrm{Ly} \times \mathrm{OC}^{3} / \mathrm{TR}^{3}+\mathrm{IL} 2 \\
10^{8} \mathrm{Ly} \times \mathrm{OC}^{3} \mathrm{TR}^{3}+\mathrm{IL} 2 \\
10^{9} \mathrm{Ly} \times \mathrm{OC}^{3} \mathrm{TR}^{3}+\mathrm{IL} 2\end{array}$ & $\begin{array}{l}\text { IL2 } \\
\text { IL2 } \\
\text { IL2 } \\
\text { IL2 }\end{array}$ \\
\hline II ( $1^{\text {st }}$ therapeutic cycle $)$ & $\begin{array}{l}6,7,8,9,10 \\
11,12\end{array}$ & $\begin{array}{l}10^{9} \mathrm{Ly} \times \mathrm{OC} / \mathrm{TR}^{4}+\mathrm{IL} 2 \\
\mathrm{IL} 2+\mathrm{OC} / \mathrm{TR}\end{array}$ & $\begin{array}{l}\mathrm{IL} 2+\mathrm{OC} / \mathrm{TR} \\
\mathrm{IL} 2+\mathrm{OC} / \mathrm{TR}\end{array}$ \\
\hline II ( $2^{\text {nd }}$ therapeutic cycle) & $\begin{array}{l}27,28,29,30,31 \\
32,33\end{array}$ & $\begin{array}{l}10^{9} \mathrm{Ly} \times \mathrm{OC} / \mathrm{TR}^{4}+\mathrm{IL} 2 \\
\mathrm{IL} 2+\mathrm{OC} / \mathrm{TR}\end{array}$ & $\begin{array}{l}\mathrm{IL} 2+\mathrm{OC} / \mathrm{TR} \\
\mathrm{IL} 2+\mathrm{OC} / \mathrm{TR}\end{array}$ \\
\hline
\end{tabular}

${ }^{1}$ The $1^{\text {st }}$ infusion was administered at 12 A.M. and the $2^{\text {nd }}$ infusion at 8 P.M. $-{ }^{2} \mathrm{Ly} \times$ OC/TR, autologous T lymphocytes targeted with OC/TR bsAb; IL-2, $0.6 \times 10^{6}$ IU IL-2; OC/TR, $1 \mathrm{mg}$ soluble OC/TR bsÄb. All infusions were given in $500 \mathrm{ml}$ of Ringer's lacate solution supplemented with $1 \%$ human serum alburnin.- ${ }^{3}$ Unbound OC/TR bsAb was washed away. $-{ }^{4}$ Unbound OC/TR bsAb was not removed.

in 2 patients ( 2 and 5). Patient 2 received a third therapeutic cycle (days 48-52). Peritoneal fluid obtained at days 48 and 54 completely inhibited OC/TR-targeted cytolysis of Igrov-1 cells. The day- 27 sample of patient 5 , obtained immediately before the start of the second phase-II therapeutic cycle (Table I), also inhibited OC/TR-targeted cytolysis of Igrov-1 cells. This sample had an exceptionally high HAMA titer (i.e., $29,550)$ in comparison to the day 27 samples of other patients (i.e., ranging between $<20$ and 267 ; patients $1,2,6,7$ and 8 ). The increased lysis of Igrov-1 target cells by untargeted $\mathrm{T}$ lymphocytes in patient 1 (days 27 and 34), patient 4 (days 13), patient 5 (days 13 and 34), patient 6 (day 27), patient 7 (days 13 and 27) and patient 8 (days 13 and 30 ) was caused by the presence of free OC/TR bsAb in those peritoneal fluid samples. This presence was detected by incubation of D11 and Igrov-1 cells in peritoneal fluid followed by indirect immunofluorescence (data not shown).

Finally, we analyzed the interaction between HAMA in peritoneal fluid samples, and (1) OC/TR-targeted cytolysis of Igrov-1 cells; (2) chOC/TR-targeted cytolysis of Igrov-1 cells, and (3) untargeted, HLA-Cw3-specific cytolysis of BSM cells, by D11 effector cells (Fig. 4). Three peritoneal fluid specimens were selected: one from patient 1, obtained on day 69 (HAMA titers [ELISA assay] against OC/TR bsAb, 896,000; against $323 / \mathrm{A} 3 \mathrm{MAb}, 17,000$ ); one from patient 2, obtained on day 48 and diluted 1:4 in C.TX medium (final HAMA titers 2,093 and 236 , respectively); and one from patient 5, obtained on day 48 (HAMA titers 193,400 and 23,500 , respectively). First, all 3 samples completely inhibited OC/TR-targeted cytolysis of Igrov-1 cells by the CTL clone D11 (Fig. 4, upper panel). A combination of human anti-idiotypic and anti-murine Igframework antibodies may be responsible for this inhibition. Second, the possible inhibitory effect of HAMA against the murine $C_{H}$ and $C_{L}$ domains was excluded in the subsequent assay in which the D11 cells were targeted using chOC/TR (Fig. 4, middle panel). The cytolysis of Igrov-1 cells by chOC/TR-targeted D11 cells was still completely inhibited in the assays with the highest HAMA concentrations, i.e., those carried out using the peritoneal fluid samples of patients 1 and 5 , whilst partial inhibition was seen in the assay with the lowest HAMA concentration, i.e., the one carried out in the 1:4 diluted peritoneal fluid from patient 2 . This observation indicates that the inhibition of OC/TR-targeted cytolytic activity by patient 2's peritoneal fluid was partly due to anti-murine $C_{H}$ and/or $C_{L}$ antibodies. Third, HAMA had no effect on untargeted, HLA-Cw3-specific cytolysis of BSM cells by the D11 effector cells (Fig. 4, lower panel).

\section{DISCUSSION}

We have studied the kinetics of HAMA responses and the interference of HAMA with OC/TR bsAb-targeted cytolysis

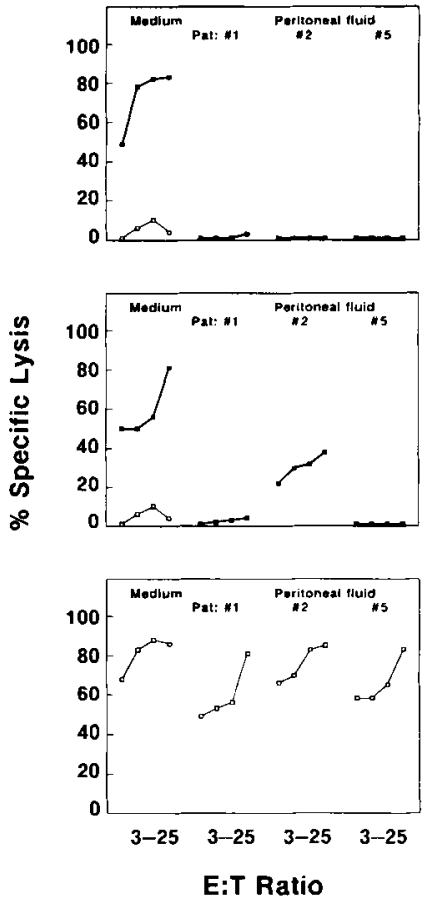

FIGURE 4 - Interaction between HAMA in peritoneal fluid and OC/TR-targeted (upper panel), chOC/TR-targeted (central panel) and HLA-Cw3-specific (lower panel) lysis by D11 CTL. The following peritoneal fluid samples were used: patient 1, day 69 (HAMA titers [ELISA assay] against OC/TR bsAb, 896,000; against 323/A3 MAb, 17,000); patient 2, day 48, 1:4 diluted (HAMA titers after 1:4 dilution, 2,093 and 236, respectively); and patient 5, day 48 (HAMA titers 193,400 and 23,500 , respectively). CTX assays using OC/TR-targeted or chOC/TR-targeted D11 CTL as effector cells are represented by closed symbols connected by bold lines; assays using untargeted D11 CTL are represented by open symbols connected by thin lines. CTX assays performed in CTX assay medium (indicated by "Medium") instead of peritoneal fluid served as positive controls in each experiment. The E:T ratios were $3,6,12$ and $25: 1$, respectively. All peritoneal fluid samples were heat-inactivated $\left(30 \mathrm{~min}\right.$ at $\left.56^{\circ} \mathrm{C}\right)$ prior to the CTX assays.

in 8 ovarian carcinoma patients receiving phase-I/II i.p. immunotherapy using OC/TR-targeted lymphocytes, soluble $\mathrm{OC} / \mathrm{TR}$ bsAb and low-dose IL-2. HAMA were detected using ELISA in serum and peritoneal fluid samples of all 8 patients from 2 and 3 weeks following start of therapy onwards, respectively, and reached peak levels at 7 weeks. These results are consistent with published data on the serum kinetics of 
primary IgG HAMA responses following intravenous (Courtenay-Luck et al., 1986) or intraperitoneal (Maher et al., 1992) administrations. A significant part of the HAMA appeared to be directed against the idiotypes of OC/TR bsAb specific for CD3 and MOv18, as suggested by (1) the clearly higher ELISA titers against OC/TR bsAb compared to those against a MAb with unrelated specificity, and (2) the failure to abrogate the capacity of peritoneal fluid to block the binding of OC/TR bsAb to $\mathrm{MOv18^{+ }}$ or $\mathrm{CD3}^{+}$cells by absorption of human anti-mouse IgG-framework antibodies in peritoneal fluid to immobilized mouse IgG. Indeed, anti-idiotypic HAMA responses have been observed in particular after repeated $\mathrm{MAb}$ administrations (Schroff et al., 1985; Courtenay-Luck et al., 1988; Saleh et al., 1993).

The specificity of HAMA for the complementarity-determining region (CDR) of MAb has been demonstrated previously using inhibition of antigen binding (Traub et al., 1988) or inhibition of anti-idiotypic antibody binding to that MAb (Chattopadhyay et al., 1991). We have followed the first approach (Fig. 2). An important observation was that peritoneal fluid samples with relatively high HAMA titers inhibit in vitro OC/TR-targeted cytolysis of ovarian carcinoma cells (Fig. 3 ). This inhibitory activity was never detected at the start of the therapeutic infusions of OC/TR-targeted T lymphocytes (i.e., phase II), but became detectable during phase II in 2 patients. This result suggests that HAMA may interfere with the goal of therapy, i.e., the in vivo destruction of tumor cells by bsAbtargeted T lymphocytes.
Strategies for overcoming the immunogenicity problem include the use of murine-human antibody constructs: chimeric MAb, composed of murine $V_{H}$ and $V_{L}$ regions combined with human $C_{H}$ and $C_{L}$ regions, or $C D R$-grafted $M A b$, which consist not only of human constant regions but also of the framework of human $\mathrm{V}_{\mathrm{H}}$ and $\mathrm{V}_{\mathrm{L}}$ regions (reviewed by Khazaeli et al., 1994). Although such molecules are probably less immunogenic than their entirely murine counterparts, they still elicit anti-idiotypic HAMA responses and, hence, antibodies with different anti-tumor idiotypes need to be used in the case of prolonged or repeated therapeutic interventions using bsAb-targeted T lymphocytes. An alternative to the use of autologous bsAb-targeted T lymphocytes is offered by genetically engineered $T$ lymphocytes endowed with receptors specific for tumor-associated antigens (Hwu et al., 1993), which may be less immunogenic.

\section{ACKNOWLEDGEMENTS}

We are grateful to Drs. S.H. Goey (Department of Medical Oncology, Daniel den Hoed Cancer Center) and J.B.M.Z. Trimbos (Department of Gynecology, University Hospital, Leiden, The Netherlands) for referral of their patients, and to Mrs. B. Luider-Vrieling for coordinative activities and technical assistance.

\section{REFERENCES}

Bénard, J., Da Silva, J., De Blois, M.C., Boyer, P., Duvilland, P., ChIRIC, E. and RIOU, G., Characterization of a human ovarium adenocarcinoma line, IGROV-1, in tissue culture and in nude mice. Cancer Res., 45, 4970-4979 (1985).

Bolhuis, R.L.H., Lamers, C.H.J., Goey, S.H., Eggermont, A.M.M., Trimbos, J.B.M.Z., Stoter, G., Lanzavecchia, A., Dl RE, E., MıotTI, S., Raspagliesi, F., Rivoltini, L. and Colnaghi, M.I., Adoptive immunotherapy of ovarian carcinoma with bs-MAb-targeted lymphocytes: a multicenter study. Int. J. Cancer, Suppl. 7, 78-81 (1992)

Bolhuis, R.L.H. and VAN DE GRIEND, R.J., PHA-induced proliferation and cytolytic activity in $\mathrm{T} 3^{+}$but not in $\mathrm{T} 3^{-}$cloned $\mathrm{T}$ lymphocytes requires the involvement of the $\mathrm{T} 3$ antigen for signal transmission. Cell. Immunol., 93, 46-57 (1985).

Chattopadhyay, P., Sneed, D., Rosenberg, J., Starkey, J., RobertSON, N., LeOnard, J. and RAychaudhur1, S., Monoclonal antiidiotypic antibodies to human melanoma-associated proteoglycan antigen: generation and characterization of anti-idiotype antibodies. Cancer Res., 51, 3183-3192 (1991).

Coney, L.R., Tomassett1, A., Carayannopoulos, L., Frasca, V., Kamen, B.A., COlnaGhI, M.I. and Zurawski, V.R., JR., Cloning of a tumor-associated antigen: MOv18 and MOv19 antibodies recognize a folate-binding protein. Cancer Res., 51, 6125-6132 (1991).

Courtenay-Luck, N.S., Epenetos, A.A., Moore, R., Larche, M., Pectasides, D., Dhokia, B. and RitTer, M.A., Development of primary and secondary immune responses to mouse monoclonal antibodies used in the diagnosis and therapy of malignant neoplasms. Cancer Res., 46, 6489-6493 (1986).

Courtenay-Luck, N.S., Epenetos, A.A., Sivolapenko, G.B., Larche, M., BARKANS, J.R. and RITTER, M.A., Development of anti-idiotypic antibodies against tumour antigens and autoantigens in ovarian cancer patients treated intraperitoneally with mouse monoclonal antibodies. Lancet, 2, 894-897 (1988).

Edwards, D.P., Grzyb, K.T., Dressler, L.G., Mansel, R.E., Zava, D.T., SLedge, G.W., JR. and McGurRe, W.L., Monoclonal antibody identification and characterization of a $\mathbf{M}_{\mathrm{r}} 43,000$ membrane glycoprotein associated with human breast cancer. Cancer Res., 46, 1306-1317 (1986)

Hwu, P., Shafer, G.E., Trejsman, J., Schindler, D.G., Gross, G., Cowherd, R., Rosenberg, S.A. and EshHar, Z., Lysis of ovarian cancer cells by human lymphocytes redirected with a chimeric gene composed of an antibody variable region and the $\mathrm{Fc}$ receptor $\gamma$ chain. J. exp. Med., 173, 361-366 (1993).

Khazaeli, M.B., Conry, R.M. and Lobuglio, A.F., Human immune response to monoclonal antibodies. J. Immunother., 15, 42-52 (1994).

Khazaeli, M.B., Saleh, M.N., Wheeler, R.H., Huster, W.J., Holden, H., Carrando, R. and Lobuglio, A.F., Phase I trial of multiple large doses of murine monoclonal antibody CO17-1A. II. Pharmacokinetics and immune response. J. nat. Cancer Inst., 80, 937-942 (1988).

Lamers, C.H.J., VAN de Griend, R.J., BraAkMan, E., Ronteltap, C.P.M., Bénard, J., Stoter, G., Gratama, J.W. and Bolhuis, R.L.H., Optimization of culture conditions for activation and largescale expansion of human $T$ lymphocytes for bispecific antibodytriggered cellular immunotherapy. Int. J. Cancer, 51, 973-979 (1992).

Lind, P., Lechner, P., Hausmann, B., Smola, M.G., Koeltringee, P., Steindorfer, P., Cesnik, H., Passl., R. and Eber, O., Development of human antimouse antibodies (HAMA) after single and repeated diagnostic application of intact murine monoclonal antibodies. Antibody Immunoconj. Radiopharmaceut., 4, 811-818 (1991).

Mach, J.P., Buchegger, F., Forni, M., Ritschard, J., Berche, C., Lumbroso, J.D., SChreYer, M., Girardet, C., ACCOlla, R.S. and CARREL, S., Use of radiolabelled monoclonal anti-CEA antibodies for the detection of human carcinomas by external photoscanning and tomoscintigraphy. Immunol. Today, 2, 239-249 (1981).

Maher, V.E., Drukman, S.J., Kinders, R.J., Hunter, R.E., JenNings, J., Brigham, C., Stevens, S. and Griffin, T.W., Human antibody response to the intravenous and intraperitoneal administration of the $F\left(a^{\prime}\right)_{2}$ fragment of the OC125 murine monoclonal antibody. J. Immunother., 11, 56-66 (1992).

Mezzanzanica, D., Canevari, S., Ménard, S., Pupa, S.M., TagliaBUE, E., LanzavecChIa, A. and ColNaghi, M.I., Human ovarian carcinoma lysis by cytotoxic $T$ cells targeted by bispecific monoclonal antibodies: analysis of the antibody components. Int. J. Cancer, 41, 609-615 (1988).

Miotti, S., Alberti, S., Facheris, P.. Mantovani, L., Fornaro, M., Stella, M., Ménard, S., Canevari, S. and Colnaghi, M.I., Membrane association and shedding of the GPI-anchored Ca-MOv18 antigen in human ovary carcinoma cells. Int. J. Cancer, 51, 499-505 (1992). 
Nitia, T., Sato, K.. Yagita, H., Okumura, K. and Ishil, S., Preliminary trial of specific targeting therapy against malignant glioma. Lancet, 335, 368-371 (1990).

Sal.eh, M.N., Khazaeli, M.B., Grizzle, W.E., Wheeler, R.H., Lawson, S., Liu, T., Russell, C., Meredith, R., SCHlom, J. and LOBUGLIO, A.F., A phase I clinical trial of murine monoclonal antibody D612 in patients with metastatic gastrointestinal cancer. Cancer Res., 53, 4555-4562 (1993).

SChrofF, R.W., FoON, K.A., BEATTY, S.M., Oldham, R.K. and MORGAN, A.C., JR., Human anti-murine immunoglobulin responses in patients receiving monoclonal antibody therapy. Cancer Res., 45 , 879-885 (1985).

SEGAL, D.M. and SNIDER, D.P., Targeting and activation of cytotoxic lymphocytes. Chem. Immunol., 47, 179-213 (1989).
Traub, U.C., De Jager, R.L., Primus, F.J., Losman, M. and GOLDENBERG, D., Anti-idiotype antibodies in cancer patients receiving monoclonal antibody to carcinoembryonic antigen. Cancer Res., 48, 4002-4006 (1988)

VAN DE Griend, R.J., Giphart, M.J., VAN Krimpen, B.A. and BolhuIS, R.L.H., Human T cell clones exerting multiple cytolytic activities show heterogeneity in susceptibility to inhibition by monoclonal antibodies. J. Immunol., 133, 1222-1229 (1984).

Van Duk, J., Warnaar, S.O., Van EendenburG, J.D.H., Thienpont, M., Braakman, E., Boot, J.H.A., Fleuren, G.J. and Bolhuis, R.L.H., Induction of tumor-cell lysis by bi-specific monoclonal antibodies recognizing renal-cell carcinoma and CD3 antigen. Int. J. Cancer, 43, 344-349 (1989). 